\title{
İlkokul Dördüncü Sınıf Öğrencilerinin Sözel ve Şekilsel Yaratıcılık Düzeylerinin İncelenmesi $^{\mathrm{a}}$
}

\author{
Memet Karakuşb, c, Mustafa Özbilgin ${ }^{\mathrm{d}}$
}

\section{Özet}

Bu araştırma ilkokul dördüncü sınıf öğrencilerinin sözel ve şekilsel yaratıcılık düzeylerini incelemek amacıyla yapılmıştır. Araştırma, ilişkisel tarama modelinde betimsel bir çalışmadır. Veri toplama aracı olarak "Yaratıcı Düşünme Testi Şekilsel Form A ve Sözel Form A" kullanılmıştır. Araştırma sonucunda, öğrencilerin sözel yaratıcılık açısından en yüksek puanı akıcılık, en düşük puanı ise orijinallik alt boyutlarında aldıkları görülmüştür. Şekilsel yaratıcılık testinde en yüksek puan ortalamasının akıcılık, en düşük puan ortalamasının ise başlıkların soyutluğu alt boyunda olduğu belirlenmiştir. Öğrencilerin sözel yaratıcılık puanları ile şekilsel yaratıcılık puanları arasında pozitif yönde ve anlamlı düzeyde bir ilişki vardır. Araştırma sonuçlarına bağlı olarak, eğitim programı ve öğretim bağlamında yaratıcı düşünme becerisinin geliştirilmesinin önemli bir amaç olarak yer alması ve özellikle yaratıcı düşünmenin esneklik ve orijinallik boyutlarını geliştirmeye yönelik olarak, okulda ve okul dışı ortamlarda eğitsel etkinliklerin yapılması önerilmiştir.
Anahtar Kelimeler

Yaratıcı Düşünme

Üst Düzey Düşünme Becerileri Eğitim

Öğretim

Makale Hakkında

Geliş Tarihi: 15.01.2020

Kabul Tarihi: 25.12.2020

Doi: $10.18026 /$ cbayarsos.675419

\section{Analysis of The Verbal and Figural Creativity Levels of Primary School Fourth Grade Students}

\begin{abstract}
This research was conducted to examine the verbal and figural creativity levels of fourth-grade students in primary school. The research designed a descriptive study in relational survey model. "Creative Thinking Test Figural Form A and Verbal Form A" were used as data collection tools. As a result of the research, it was seen that the students had the highest score in fluency and the lowest score in the subtitle of originality in terms of verbal creativity. In the figural creativity test, the highest average score was found to be fluency and the lowest average score was in the abstraction of titles sub-dimension. There is a positive and significant relationship between verbal creativity scores and figural creativity scores. Depending on the results of the research, it has been suggested that the development of creative thinking skills should be an important objective in the context of the education program and teaching, and educational activities should be carried out in school and out-of-school settings, especially in order to develop the creative thinking to the flexibility and originality dimensions.
\end{abstract}

Keywords

Creative thinking High order thinking skills

Education

Teaching

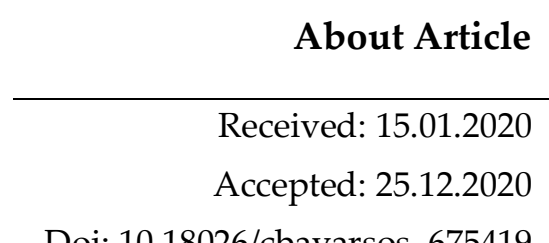

Doi: 10.18026/cbayarsos. 675419

\footnotetext{
a Uluslararası Aktif Öğrenme Sempozyumunda bildiri olarak sunulmuştur. Adana/06-08 Eylül 2019

b İletişim Yazarı: memkks@gmail.com

c Doç. Dr., Çukurova Üniversitesi Eğitim Fakültesi Eğitim Bilimleri Bölümü, ORCID: 0000-0002-6099-5420

d Öğretmen, Milli Eğitim Bakanlığı, mustafaozblgn@gmail.com, ORCID: 0000-0003-2982-7231
} 


\section{Giriş}

Toplumlar daha nitelikli insanlar yetiştirebilmek için, eğitime büyük önem vermektedir. Artık ülkelerin refahını belirleyen temel unsur üretim, üretimin belirleyicisi ise iyi yetişmiş ve yaratıcılığı yüksek insan gücüdür. Yaratıcılık, üretimde verimliliğin ve çeşitliliğin artırılmasında ihtiyaç duyulan en temel etkenlerden biridir. Üreticiliği yaşam biçimine dönüştürmüş, gelişmiş toplumlarda üretme eylemi yaşamın tamamına hakim olduğu için buna bağlı olarak yaratma eylemi ya da yaratıcılık yetisi de aynı oranda yaşam stiline dönüşmüştür. Yaratıcılık, her insanda potansiyel bulunan bir yetidir. Fakat bu yetiyi her insanın sergileyişi, pratiğe aktarışı farklıdır. Bu farklılığın nedeni görülen eğitime ve eğitimin düzeyine, yaşanılan çevreye ve kalıtıma bağlıdır (Kırışoğlu, 2002). Yaratıcılık kişinin çevresine uyum sağlaması, öğrenmesi ve duyularının gelişmesi için önemlidir. Yaratıcı süreç, kendini gerçekleştirmenin gelişimidir. Yaratıcı gelişme sağlamak ya da kendini gerçekleştirmek, insan oluşumuna yönelik atılan adımlardır. Yaratıcılık; bir düşünce, ürün etkinlik veya süreç olarak ortaya çıkabilir. Yaratıcılık her bireyde vardır. Bu yüzden, yaratıcılığı geliştirme çabası eğitimin, ailelerin ve hatta toplumun vazgeçilmez bir görevi olmalıdır (Addington, 1997). Bu açıklama yaratıcılığı geliştirme çabasını bir adım daha ileri götürerek toplumun vazgeçilmezleri arasına koymaktadır. Herhangi bir konunun ya da kavramın toplumsal vazgeçilmezler listesinde olabilmesi için toplumun o kavramdan azami derecede fayda sağlaması ve bu faydanın bilincinde olması gerekir. Ancak bu bilinçle yaratıcılık toplumda ve eğitimde daha iyi tutunabilir. Pek çok gelişmenin temelinde olduğu gibi yaratıcılığın gelişiminin temelinde de hayal kurma becerisi yer almaktadır (Bayındır, 2013: s. 34). Yaratıcı düşünme, çocukların yeni düşünceler üretmeleri, hipotezler önermeleri, hayal güçlerini kullanmaları ve alternatif sonuçlar aramalarına katkı sağlar (Wegerif, 2007).

Yaratıcı düşünme odaklı olarak yapılan öğretim uygulamalarının öğrencilerin, bilimsel yaratıcılık düzeylerini geliştirmesinin yanında tasarlama ve geliştirme beceri düzeylerini de olumlu yönde etkilediği sonucuna ulaşılmıştır (Kurtuluş, 2012). Yapılacak olan her yeni şeye önce hayal edilerek başlandığ 1 düşünüldüğünde, hayal gücü aslında her yeniliğin başlangıc1 olarak karşımıza çıkar. Okul, bir çocuğa öğrettikleri ve hayatına yaptığı katkılarla çocuğun ailesinden sonra gelen en önemli kurum olma özelliği taşır. Okulda çocuğa verilen bilgi ezber ve kalıp bilgi olmak yerine çocuktaki yaratıcılığı geliştirecek şekilde tasarlanmalıdır. Ancak, okullar öğrencilerde rraksak düşüncenin gelişimi yerine, yakınsak düşüncenin gelişimine katkı sunmaktadır. Öğrenciye okulda öğretilenlerin aynısının sınavlarda sorulması ve en iyi cevap verenlere en yüksek puanları alması, öğrencinin bilgiyi özümsemesine, ona kendinden bir şeyler katarak geliştirmesine engel olduğu öngörülmektedir. Yaratıcı etkinlikler sonucunda elde edilen ürünler, uzmanların çocukları daha iyi tanıması için önemli bir şans olmuştur. Çocuklar düşüncelerini her zaman sözlü olarak ifade edemedikleri için, yaratıcılıkla ilgili yapılan etkinlikler açıklanması zor olan birçok duruma ışık tutmuştur (Fındıkçı, 1988, Akt. Karakuş, 2001).

Yaratıcılık alanında pek çok çalışma yapmış olan Torrance (2002), yaratıcılıkta bir tekel olmadığını ve yaratıcılıkta okulların işlevden fazlasına, sorumluluğa sahip olduğunu vurgulamaktadır. Yaratıcılığın gelişiminde çevrenin etkisini vurgulayan Torrance (2002) aslında bununla da herkesin iyi bir eğitimden geçmesinin, gelecek kuşakların yaratıcılığının gelişimi için gerekli olduğunu anlatmaktadır. İyi bir eğitimle kastedilen ise yenilikçi eğitim anlayışıdır. Geleneksel eğitim sistemleri çoğunlukla yaratıcılığa gereken önemi verememektedir. Geleneksel eğitim sisteminde bilgi önceden araştırılmış, doğruluğu 
sınanmış, kesin yargılarla sınırları çizilmiş kavramlardır. Öğrencilerin bu bilgileri araştırmadan, düşünmeden, eleştirmeden olduğu gibi kabul etmeleri beklenmektedir. Böyle bir sistemin yaratıcı öğrenciler yetiştirmesi beklenemez (Koray, 2003). Eğitim programları hazırlanırken öğrencileri mümkün olduğu kadar özgün, kendilerini ifade edebilen bireyler olarak yetiştirmek amaçlanmalıdır.

İlkokula başlayan öğrenciler okulun ilk yıllarında belirli bir düzeyde yaratıcllık yeteneği ile okula gelirler mevcut bu potansiyelin geliştirilmesi ve kullanılması için bu yıllar çok önemlidir (Erdoğdu, 2006). Derslerin matematik ağırlıklı işlendiği bir eğitim ortamında sol beynin gelişimi desteklenir ve bu durum sağ beyin küresi ile yetenekleri gelişen öğrenciler için zorluklar oluşturur. Bu nedenle ilköğretim programları hazırlanırken beynin her iki küresinin gelişimi dikkate alınarak hazırlanmalıdır (Karakuş, 2001). Beynin sağ ve sol olmak üzere iki yarım küresi vardır. Bunlardan sol yarım küre daha çok soyut kavramların işlendiği, sağ yarım küre ise somut bilgilerin işlendiği kısımdır. Bu iki yarı küreyi dengeli olarak geliştirmek kişinin hem yetenekleri için önemlidir hem de ruhsal dengesi için önemlidir. Bu bütünlüğü korumak ise eğitim programlarının temel amaçlarından biri olmalıdır. Eğitim programları ve okuldaki işleyişin yönlendiricisi konumunda olan yöneticiler ve öğretmenler öğrencilerdeki yaratıcılığ 1 pratiğe aktarmada onlara yeterince imkan tanımamaktadır. Bu durum ise haklı olarak eleştirileri beraberinde getirmektedir. Okullarda verilen eğitim öğrencilerin yaratıcılıklarını zayıflatmakta ve okuldaki bürokratik ortam öğrencilerin enerjisinden çok zamanını çalmaktadır (Karakuş, 2001). Okuldaki bürokratik ortam nedeniyle pek çok etkinliğin yapılabilmesi için uzun süre beklemek gerekmekte ve bu durum öğrencilerin yaratıcılıklarını ve üretkenliklerini olumsuz etkilemektedir. Okulun öğrencilerden beklentileri genellikle kurallara uyma, derste pasiflik, ödevler, söylenenin dışına çıkmama ve bilinçsizce okula gidip gelmeler olduğu için aslında günün yaşanmadan geçmesine sebep olmaktadır. Zaman kavramı üretilemeyen ve tekrarı olmayan bir süreç olması nedeniyle kullanımı ve yönetimi çok önemli olan bir kavramdır. Okullar zaman kavramını verimli kullanarak pek çok şeyin öğretilmesi için en uygun zamanda kendileri ile buluşan öğrencilerin daha çok ve verimli öğrenmelerini sağlayacağ gibi zamanın iyi değerlendirilmemesi ile de öğrencilerin zamanından çalmış olacaktır.

Okullardaki yaratıcılığa yönelik olumlu ya da olumsuz ortamlar yaratıcılık üzerinde önemli bir etkiye sahiptir. Torrance (1968, Akt: Öncü, 1989), ilkokullar üzerinde yapmış olduğu çalışmada, okuldaki eğitim sisteminin yaratıcılığı körelttiği sonucuna ulaşmıştır. İlkokulda üçüncü sınıfa kadar yüksek yaratıcılığa sahip çocuklar, gerek öğretmenler, gerekse sınıftaki arkadaşları tarafından fikirlerinin "saçma" oldukları ve "haylazca düşündükleri" için eleştirilere maruz kalmışlar ve üçüncü sınıfın sonlarına doğru fikirlerini kendilerine saklamayı tercih ettikleri görülmüştür. Öncü (2014, s. 88), okul kavramından, bina, fiziksel özellikler, okul çalışanları ve okulda uygulanan öğretim programlarının akla geldiğini fakat bir okulun yaratıcı okul olabilmesi için tüm bu unsurların yaratıcılığ gereken olanakları sunabilmesi gerektiğini aktarmıştır. Öğrencilerin keşfetmelerine imkan tanıyan, araştırmayı destekleyen ve eğlenceli bir ortam sunabilen okulların yaratıcılığı geliştirebildiğini aksi takdirde yaratıcılığın köreltildiğini belirtmiştir.

Öğrencilerde yaratıcılığı geliştirebilmek için pek çok argümanın bir arada ve uyum içerisinde olması gerekir. Bunlardan; eğitim programları, yaratıcılığı geliştirici sınıf ortamı, öğretmen ve aile ilk akla gelenlerdir. Öğretmen faktörü eğitimdeki pek çok konunun temel belirleyicisi konumundadır. Kuyubaşıŏlu (2009), yapmış olduğu araştırmada buna ilişkin bulgular elde 
etmiştir. Bu çalışmada mesleki kıdemi daha yüksek olan öğretmenlerin yaratıcı düşünme becerilerini daha az benimsedikleri ortaya çıkmıştır. Öğretmenlerin yaratıcılığa ilişkin aldıkları hizmet içi eğitim, eğitim durumları, yaratıılığa ilişkin bakış açıları, mesleki kıdemleri ve yaşları gibi etkenler sınıftaki yaratıcı düşünme ortamını etkileyen unsurlar olduğu için, etkili yaratıcılık eğitimi için öğretmen eğitimi büyük önem taşımaktadır. Yaratıcı düşünmeye dayalı öğrenme yaklaşımları öğrencilerin yaratıcı düşünme becerilerinin gelişmesinde etkilidir. Öztürk'ün (2007) yaptığı araştırmada yaratıcı düşünmeye dayalı öğretim yaklaşımlarının öğrencilerin akıcılık, esneklik ve orijinallik gibi yaratıcı düşünme becerilerinin gelişmesinde etkili olduğu görülmüştür. Yine bu araştırmada öğretmen merkezli yaklaşımın yaratıcı düşünme becerilerinin dört boyut (akıcılık, esneklik, ayrıntılılık, orijinallik) açısından da herhangi bir gelişme tespit edilmediği ortaya çıkmıştır. Öğrencilerin yaratıcılığına etki eden unsurlardan bir diğeri ise ders kitaplarıdır. Okulda öğrencilerin bilgiye ulaştığ 1 başlıca kaynak olması sebebiyle ders kitaplarının içeriğinin yaratıcılığa etkisi önemlidir. Ders kitapları belli sınıf düzeylerinde ve bazı dersler için öğrenme-öğretme sürecine doğrudan etki edebilmektedir. Ders kitaplarındaki konular, konuların işlenişi ve etkinlikler öğrencilerin yaratıcılıklarını etkilemektedir. Palandökenliler (2008), yapmış olduğu çalışmada ders kitaplarındaki etkinliklerde yaratıcı içeriğin sınırlı olduğunu tespit etmiş ve bu etkinliklerin düşük düzeyde akıcı, esnek ve özgün ürünler ortaya çıkardığını belirtmiştir. Ders kitaplarını hazırlayanlar kitapların sadece öğretici bir materyal olarak hazırlamak yerine yaratıcı, merak uyandıran, eğlenceli bir kaynak haline getirerek ders kitaplarının işlevselliğini arttırabilirler.

Yaratıcılığa verilen değer konusunda yapılan araştırmalar incelendiğinde, yaratıcılı̆̆ın eğitimde neredeyse uygulamaların merkezi konumunda olduğu görülmektedir. Eğitim sürecinin başat simgelerinden biri de yaratıcılıktır (Gibson, 2005, Akt. Avcu, 2014). Buna karş1 bir iddia ise, yaratıcılığı körelten unsurlar arasında okulların ve eğitimcilerin de olduğu yönündedir (Robinson, 2005). Buradaki eleştiri ise programdan, öğretmen donanımına kadar pek çok alanı kapsamaktadır. Ayrıca Orhon (2014), yaratıcılı̆̆ın öğretmen özellikleri, özel tasarlanmış programlar ile geliştirilebileceği gibi tam tersi olarak kısır öğretim programı ve yetersiz öğretmen ile de yok edilebileceğini belirtmiştir. Ayrıca, yaratıcılık alanında yapılan araştırmalar incelendiğinde, ilkokul düzeyinde yapılan çalışmaların diğer okul kademelerinde yapılan çalışmalara göre daha az olduğu, yaratıcı düşünme becerilerini sözel ve şekilsel olarak birlikte inceleyen çalışmaların çok az olduğu belirlenmiştir. Bu çalışmanın yaratıcılıkla ilgili yapılan diğer çalışmalardan en önemli farkı, çok sınırlı sayıda araştırmada ele alınan şekilsel yaratıcılığı incelemesi ve şekilsel yaratıcılıkla sözel yaratıcılığı karşılaştırmasıdır. Bu açıklamalar doğrultusunda, araştırmanın problem cümlesi, "İlkokul 4. sınıf öğrencilerinin sözel ve şekilsel yaratıcılık düzeyleri nedir?" şeklinde ifade edilmiştir. Bu doğrultuda araştırmada aşağıdaki sorulara cevap aranmıştır:

a. Öğrencilerin sözel ve şekilsel yaratıcılık düzeyleri nedir?

b. Öğrencilerin cinsiyetlerine göre sözel ve şekilsel yaratıcılık düzeyleri arasında anlamlı bir fark var mıdır?

c. Öğrencilerin sözel yaratıcı düşünme düzeyleri ile şekilsel yaratıcı düşünme düzeyleri arasında anlamlı düzeyde bir ilişki var mıdır?

d. Öğrencilerin yaratıcı düşünme düzeyleri ile okuldaki akademik başarıları arasında anlamlı düzeyde bir ilişki var mıdır? 


\section{Yöntem}

\section{Araştırma Modeli}

Betimsel ve nicel yönteme göre tasarlanan araştırma, ilişkisel tarama modelindedir. İlişkisel tarama modeli, iki veya daha fazla sayıdaki değişken arasındaki değişimi veya değişim derecesini belirlemeyi hedefleyen araştırma modelidir( Karasar, 2012: s. 79-81).

\section{Evren ve Örneklem / Çalışma Grubu / Katılımcılar}

Araştırmanın evrenini Osmaniye ili Düziçi ilçesinde öğrenim gören ilkokul öğrencileri oluşturmaktadır. Araştırmanın örneklemini ise Osmaniye ili Düziçi ilçesinde üç farklı ilkokulda 4. sınıfta öğrenim gören 35 erkek, 44 kızdan oluşan toplam 79 öğrenci oluşturmaktadır.

\section{Veri Toplama Araçları}

Araştırmada veri toplama aracı olarak Torrance Yaratıcı Düşünme Testi (TYDT) Sözel ve Şekilsel formları kullanılmıştır. Sözel yaratıcılığı ölçmek amacıyla geliştirilen sözel yaratıcılık testi; "Soru Sorma, Nedenleri Tahmin Etme, Sonuçları Tahmin Etme, Ürün Geliştirme, Alışılmadık Kullanımlar, Alışılmadık Sorular Ve Farz Edin ki” alt başlıkları olmak üzere toplam yedi alt başlıktan oluşur ve bu testte katılımcının düşüncelerini yazması istenir. Bireylerin şekilsel yaratıcılıklarını ölçme amacıyla geliştirilen şekilsel test ise; "Resim Oluşturma, Resim Tamamlama, Daireler/Parelel Çizgiler" alt başlıkları olmak üzere toplam üç alt başlıktan oluşur ve bu testte katılımcıdan düşüncelerini çizimler yaparak ifade etmeleri istenir. TYDT'de kullanılan sözel ve şekilsel testler ve bu testlerin A ve B formları Amerikan örneklemiyle Torrance tarafından gerçekleştirilen geçerlik ve güvenirlik çalışmalarının sonucunda yaratıcılığı ölçmede yeterli geçerliğe ve güvenirliğe sahip olduğu ispatlanmıştır (Torrance, 1966, 1974; Öncü, 2000). Bu araştırmada kullanılan TYDT’lerin geçerlik ve güvenirliğini belirlemek için bazı çalışmalar yapılmıştır. Bu amaçla uygulama yapılmadan önce küçük bir grup üzerinde testteki maddeleri gerçekten anlayıp anlamadıkları test edilmiştir. Öğrencilerin soruları gerçekten anladıkları görülmüştür. Şekilsel test için de öğrencilerin testin yönergesini gerçekten anlayıp anlamadığına yönelik çalışmalar yapılmıştır. $\mathrm{Bu}$ konuda da sorun olmadığı gözlenmiştir. Sözel ve şekilsel TYDT’lerin güvenirliğini belirlemek amacıyla rastlantısal olarak seçilen 32 Test iki farklı puanlayıcı tarafından puanlanmıştır. Puanlayıcılardan biri araştırmacı diğeri ise yaratıcılık konusunda eğitim alan ve bu konuda tez hazırlamakta olan bir öğretmendir. İki puanlayıcı arasındaki korelasyon değeri .97 çıkmıştır. Bu durum puanlayıcılar arasında çok yüksek bir tutarlığın olduğu anlamına geldiği için(Can, 2014), TYDT'lerin puanlayıcı güvenirliğinin yüksek olduğu söylenebilir.

\section{Verilerin Toplanması ve Analizi}

Araştırmada veri toplama sürecinde önce sözel yaratıcılık testi uygulanmış, diğer gün ise şekilsel yaratıcılık testi uygulanmıştır. Testlerin uygulama süreçleri yaklaşık olarak 60 dakika sürmüştür. Akademik başarı puanları olarak ise öğrencilerin Türkçe ve Matematik dersindeki yıl sonu ortalamaları alınmıştır. Torrance Yaratıcı Düşünme Testleri aracılığıyla toplanan veriler spps paket programı aracılığıyla incelenmiştir. İstatistiksel olarak normallik sayıltısını test etmek için, veriler Kolmogorov-Smirnov ve Shapiro-Wilk test teknikleriyle analiz edilmiştir. Normallik sayıltısının karşılandığı durumlarda ikili karşılaştırmalar için t testi kullanılmıştır (Sözel ve şekilsel orijinallik puanları ile toplam sözel yaratıcılık puanları 
için $\mathrm{p}>.05$; diğer değişkenlere yönelik puanların tamamında $\mathrm{P}<.05$ bulunmuştur). Normallik sayıltısının sağlanmadığı verilerin analizinde ise Mann Whitney-U testi kullanılmıştır. Öğrencilerin yaratıcılık düzeyleri ile akademik başarıları arasındaki ilişkiyi incelemek için, veriler normallik koşulunu sağlamadığı için Spearmen Sıra Farkları korelasyonu hesaplanarak analiz yapılmıştır. Öğrencilerin sözel yaratıcı düşünme düzeyleri ile şekilsel yaratıcı düşünme düzeyleri arasındaki ilişkiyi incelemek için de, veriler normallik koşulunu sağladığı için Pearson basit doğrusal korelasyon analizi yapılmıştır. Betimsel değerler için aritmetik ortalama ya da sıra ortalamaları kullanılmıştır.

\section{Bulgular}

Öğrencilerin sözel yaratıcılık düzeylerine yönelik bulgular

Öğrencilerin TYDT Sözel formundan aldıkları puanlara yönelik betimsel istatistik sonuçları Tablo 1'de verilmiştir.

Tablo 1. Öğrencilerin Sözel Yaratıcılık Düzeylerine Yönelik Betimsel Değerler

\begin{tabular}{|c|c|c|c|c|c|}
\hline \multirow{2}{*}{$\begin{array}{l}\text { TYDT SÖZEL } \\
\text { FORM }\end{array}$} & \multirow{2}{*}{$\mathbf{N}$} & \multicolumn{2}{|c|}{ En Düşük En Yüksek } & \multirow{2}{*}{$\overline{\boldsymbol{X}}$} & \multirow{2}{*}{ SS } \\
\hline & & Puan & Puan & & \\
\hline Akıcılık & 79 & 18.00 & 87.00 & 46.89 & 14.92 \\
\hline Esneklik & 79 & 8.00 & 31.00 & 18.83 & 4.71 \\
\hline Orijinallik & 79 & 1.00 & 37.00 & 16.89 & 7.61 \\
\hline $\begin{array}{c}\text { Toplam } \\
\text { Yaratıcilık }\end{array}$ & 79 & 12.00 & 47.33 & 27.54 & 8.29 \\
\hline
\end{tabular}

Tablo 1'de görüldüğ̈̈ gibi öğrencilerin TYDT'den aldıkları sözel akıcılık puanlarının ortalaması x: 46.89, sözel esneklik puanlarının ortalaması x: 18.83, sözel orijinallik puanlarının ortalaması $\overline{x:} 16.89$, sözel yaratıcılık puanları toplamının ortalaması ise $\bar{x}$ : 27.54 'tür. Bu tabloya göre öğrencilerin akıcılık puanlarının en yüksek, orijinallik puanlarının ise en düşük olduğu söylenebilir.

Öğrencilerin Cinsiyetlerine Göre Sözel Yaratıcılık Düzeylerine Yönelik Bulgular

Öğrencilerin cinsiyetlerine göre TYDT sözel yaratıcılık testinden aldıkları puanların aritmetik ortalamaları ve standart sapmaları ile yapılan $\mathrm{t}$ testi analizinin sonuçları Tablo 2'de verilmiştir. 
Tablo 2. Öğrencilerin Cinsiyetlerine Göre Sözel Yaratıcılık Düzeylerine Yönelik Betimsel Değerler

\begin{tabular}{lccccccc}
\hline Yaratıcılık Cinsiyet & $\mathbf{N}$ & $\overline{\boldsymbol{X}}$ & $\mathbf{S S}$ & $\mathbf{d f}$ & $\mathbf{t}$ & $\mathbf{p}$ \\
\hline \multirow{2}{*}{ Akıc1lık } & Kız & 44 & 46.72 & 14.05 & 77 & -.11 & .91 \\
& Erkek & 35 & 47.11 & 16.15 & 67.81 & -.11 & .91 \\
\multirow{2}{*}{ Esneklik } & Kız & 44 & 18.63 & 4.87 & 77 & -.41 & .67 \\
& Erkek & 35 & 19.08 & 4.56 & 74.89 & -.42 & .67 \\
\multirow{2}{*}{ Orijinallik } & Kız & 44 & 17.27 & 7.28 & 77 & .48 & .62 \\
& Erkek & 35 & 16.42 & 8.08 & 69.24 & .48 & .63 \\
\multirow{2}{*}{ Toplam } & Kız & 44 & 27.54 & 7.78 & 77 & .00 & .99 \\
& Erkek & 35 & 27.53 & 9.01 & 67.52 & .00 & .99 \\
\hline
\end{tabular}

Tablo 2'de görüldüğ ü gibi kız öğrencilerin TYDT'den aldıkları sözel akıcılık puanlarının ortalaması x: 46.72, esneklik puanlarının ortalaması $\bar{x}$ : 18.63 , orijinallik puanlarının ortalaması ise $\overline{x:} 17.27$ 'dir. Erkek öğrencilerin TYDT'den aldıkları sözel akıcılık puanlarının ortalaması $\overline{\mathrm{x}}$ 47.11, esneklik puanlarının ortalaması $\overline{\mathrm{x}}$ : 19.08 , orijinallik puanlarının ortalaması ise $\overline{\mathrm{x}}$ 16.42 'dir. Cinsiyet açısından öğrencilerin sözel yaratıcılı̆̆ın alt boyutları arasında farklar olsa $\mathrm{da}$, cinsiyet açısından her iki grubunda sözel puanlarının ortalamaları (x: 27.53) birbirine eşittir. Fakat toplamda standart sapma değerleri farklı olduğu ve farklılaşmanın erkeklerde daha fazla olduğu görülmektedir. Tablo 2' de görüldüğü gibi cinsiyete göre öğrencilerin sözel yaratıcılık düzeyleri arasında anlamlı düzeyde bir fark yoktur.

Öğrencilerin Şekilsel Yaratıcı Düşünme Düzeylerine Yönelik Bulgular

Öğrencilerin TYDT şekilsel formundan aldıkları puanlara yönelik betimsel istatistik sonuçları Tablo 3'te verilmiştir. 
Tablo 3. Öğrencilerin Şekilsel Yaratıcılık Düzeylerine Yönelik Betimsel Değerler

\begin{tabular}{|c|c|c|c|c|c|}
\hline Yaratıcılık & $\mathbf{N}$ & $\begin{array}{l}\text { En Düşük } \\
\text { Puan }\end{array}$ & $\begin{array}{c}\text { En Yüksek } \\
\text { Puan }\end{array}$ & $\bar{X}$ & SS \\
\hline$\overline{\text { Akıcıllk }}$ & 79 & 7.00 & 40.00 & 27.53 & 8.46 \\
\hline Orijinallik & 79 & 4.00 & 32.00 & 18.79 & 6.28 \\
\hline $\begin{array}{l}\text { Başlıkların } \\
\text { Soyutluğu }\end{array}$ & 79 & .00 & 19.00 & 3.32 & 4.03 \\
\hline Zenginleştirme & 79 & 3.00 & 12.00 & 6.92 & 1.71 \\
\hline $\begin{array}{l}\text { Erken Kapamaya } \\
\text { Direnç }\end{array}$ & 79 & .00 & 13.00 & 6.12 & 3.18 \\
\hline $\begin{array}{l}\text { Yaratıcı } \\
\text { Kuvvetler }\end{array}$ & 79 & .00 & 43.00 & 11.02 & 8.80 \\
\hline $\begin{array}{l}\text { Toplam } \\
\text { Yaratıcilık }\end{array}$ & 79 & 23.00 & 137.00 & 73.77 & 21.53 \\
\hline
\end{tabular}

Tablo 3'te görüldüğü gibi öğrencilerin TYDT'den aldıkları şekilsel akıcılık puanlarının ortalaması $\overline{\mathrm{x}}$ : 27.53, şekilsel orijinallik puanlarının ortalaması $\overline{\mathrm{x}}$ : 18.79, Şekilsel başlıkların soyutluğu (BS) puanlarının ortalaması x: 3.32, şekilsel zenginlik puanlarının ortalaması $\overline{\mathrm{x}}$ : 6.92 , şekilsel erken kapamaya direnç (EKD) puanlarının ortalaması $\overline{x:} 6.12$, yaratıcı kuvvet puanlarının ortalaması $\overline{\mathrm{x}:} 11.02$ ' dir. Şekilsel yaratıcılık puanlarının ortalaması ise $\overline{\mathrm{x}^{\prime}} \mathbf{7 3 . 7 7 ^ { \prime }}$ dir. Şekilsel yaratıcılık testinde en yüksek puan ortalamasının akıcılık alt başlığında, en düşük puan ortalamasının ise başlıkların soyutluğu alt boyunda olduğu görülmektedir.

Öğrencilerin cinsiyetlerine göre TYDT şekilsel yaratıcılık testinden aldıkları puanların sıra ortalamaları ve standart sapmaları Tablo 4 'te verilmiştir. 
Tablo 4. Öğrencilerin Cinsiyetlerine Göre Şekilsel Yaratıcılık Düzeylerine Yönelik Betimsel Analizler

\begin{tabular}{|c|c|c|c|c|c|c|c|}
\hline $\begin{array}{l}\text { TYDT } \\
\text { ŞEKİLSEL } \\
\text { FORM }\end{array}$ & Cinsiyet & $\mathbf{N}$ & $\begin{array}{l}\text { Sira } \\
\text { Ortl. }\end{array}$ & $\begin{array}{l}\text { Sira } \\
\text { Toplamı }\end{array}$ & $\begin{array}{c}\text { Mann- } \\
\text { Whitney } \\
\text { U }\end{array}$ & $\mathbf{p}$ & Fark \\
\hline \multirow{2}{*}{ Akıcılık } & $\mathrm{K} 1 \mathrm{z}$ & 44 & 41.95 & 1846.00 & \multirow{2}{*}{684} & \multirow{2}{*}{.39} & \\
\hline & Erkek & 35 & 37.54 & 1314.00 & & & \\
\hline \multirow{2}{*}{ Orijinallik } & $\mathrm{K}_{1 \mathrm{Z}}$ & 44 & 44.72 & 1967.50 & \multirow{2}{*}{562.50} & \multirow{2}{*}{.04} & \multirow{2}{*}{$\mathrm{K}>\mathrm{E}$} \\
\hline & Erkek & 35 & 34.07 & 1192.50 & & & \\
\hline \multirow{2}{*}{$\begin{array}{l}\text { Başlıkların } \\
\text { Soyutluğu }\end{array}$} & $\mathrm{K}_{1 \mathrm{Z}}$ & 44 & 40.16 & 1767.00 & \multirow{2}{*}{763.00} & \multirow{2}{*}{.94} & \\
\hline & Erkek & 35 & 39.80 & 1393.00 & & & \\
\hline \multirow{2}{*}{ Zenginleştirme } & $\mathrm{K} 1 \mathrm{Z}$ & 44 & 46.03 & 2025.50 & \multirow{2}{*}{504.50} & \multirow{2}{*}{.008} & \multirow{2}{*}{$\mathrm{K}>\mathrm{E}$} \\
\hline & Erkek & 35 & 32.41 & 1134.50 & & & \\
\hline \multirow{2}{*}{$\begin{array}{l}\text { Erken } \\
\text { Kapamaya } \\
\text { Direnç }\end{array}$} & $\mathrm{K}_{1 \mathrm{Z}}$ & 44 & 42.57 & 1873.00 & \multirow[b]{2}{*}{657.00} & \multirow[b]{2}{*}{.26} & \\
\hline & Erkek & 35 & 36.77 & 1287.00 & & & \\
\hline \multirow{2}{*}{$\begin{array}{l}\text { Toplam } \\
\text { Yaratici } \\
\text { Kuvvetler }\end{array}$} & $\mathrm{K}_{1 \mathrm{Z}}$ & 44 & 43.65 & 1920.50 & \multirow[b]{2}{*}{609.50} & \multirow[b]{2}{*}{.11} & \\
\hline & Erkek & 35 & 35.41 & 1239.50 & & & \\
\hline \multicolumn{2}{|c|}{ Toplam ŞekilselKız } & 44 & 43.97 & 1934.50 & \multirow{2}{*}{595.50} & \multirow{2}{*}{.08} & \\
\hline Yaratıcılık & Erkek & 35 & 35.01 & 1225.50 & & & \\
\hline
\end{tabular}

Tablo 4'te görüldüğü gibi cinsiyete göre öğrencilerin TYDT şekilsel puanlarının sıra ortalamaları arasında farklılıklar vardır. Tablo 4'e göre cinsiyete göre öğrencilerin TYDT şekilsel puanları sadece şekilsel orijinallik $(\mathrm{p}=.04)$ ve şekilsel zenginlik $(\mathrm{p}=.00)$ açısından, $\mathrm{p}$ $<.05$ düzeyine göre anlamlı şekilde farklılaşmaktadır. Şekilsel yaratıcllık testinden alınan puanlar açısından anlamlı düzeyde farkın olduğu alt boyutlarda, farkın sıra ortalaması erkeklere göre daha yüksek olan kızlar lehine olduğu söylenebilir.

Öğrencilerin Sözel Yaratıcı Düşünme Düzeyleri İle Şekilsel Yaratıcı Düşünme Düzeyleri Arasındaki İlişkiye Yönelik Bulgular

Öğrencilerin sözel yaratıcı düşünme düzeyleri ile şekilsel yaratıcı düşünme düzeyleri arasındaki ilişkinin düzeyini incelemek için, değişkenler arasındaki ilişkiye yönelik Pearson korelasyon katsayısı incelenmiştir. Analiz sonuçları Tablo 5' de verilmiştir. 
Tablo 5. Öğrencilerin Sözel Yaratıcı Düşünme Düzeyleri İle Şekilsel Yaratıcı Düşünme Düzeyleri Arasındaki İlişkiye Yönelik Korelasyon Analizi Bulguları

\begin{tabular}{lc}
\hline Korelasyon & Şekilsel Yaratıcılık \\
\hline Sözel Yaratıcılık & $.30^{* * *}$ \\
P & .00 \\
N & 79 \\
\hline
\end{tabular}

Tablo 5 incelendiğinde sözel yaratıcılık puanları ile şekilsel yaratıcılık puanları arasında pozitif yönde 30 düzeyinde düşük bir ilişki olduğu ve bu ilişkinin $p<.001$ düzeyine göre anlamlı olduğu söylenebilir.

Öğrencilerin Okuldaki Akademik Başarı Düzeylerine Yönelik Bulgular

Öğrencilerin okuldaki Türkçe ve matematik derslerine yönelik akademik başarılarına yönelik bulgular Tablo 6' da verilmiştir.

Tablo 6. Öğrencilerin Akademik Başarı Düzeylerine Yönelik Mann-Whitney U Testi Analiz Sonuçlar

\begin{tabular}{lccccc}
\hline $\begin{array}{l}\text { Akademik } \\
\text { Başarı }\end{array}$ & $\mathbf{N}$ & $\begin{array}{c}\text { Sıra } \\
\text { Ortalaması }\end{array}$ & $\begin{array}{c}\text { Sıra } \\
\text { Toplamı }\end{array}$ & U & p \\
\hline Matematik & 79 & 76.18 & 6018.00 & 2858 & .36 \\
Türkçe & 79 & 82.82 & 6543.00 & & \\
\hline
\end{tabular}

Öğrencilerin not ortalamaları arasında anlamlı farkın olup olmadığına bakmak için MannWhitney $U$ testi yapılmıştır. Tablo 6 'da görüldüğü gibi öğrencilerin Türkçe dersi notlarının sira ortalamasının 76.18, Matematik dersi notlarının sıra ortalamasının ise 82.82 'dir. Sira ortalamaları arasındaki farkın anlamlılık düzeyini incelemek için yapılan Mann-Whitney $U$ Testi analizine göre matematik ve Türkçe derslerinden alınan puanlar arasında $\mathrm{p}<.05$ düzeyine göre anlamlı bir fark yoktur.

Öğrencilerin Yaratıcı Düşünme Düzeyleri İle Akademik Başarıları Arasındaki İlişkiye Yönelik Bulgular

Öğrencilerin yaratıcı düşünme düzeyleri ile akademik başarı düzeyleri arasındaki ilişkinin düzeyini incelemek için, değişkenler arasındaki ilişkiye yönelik Spearman's Rho korelasyon katsayısı incelenmiştir. Analiz sonuçları Tablo 7'de verilmiştir. 
Tablo 7. Öğrencilerin Yaratıcı Düşünme Düzeyleri İle Akademik Başarı Düzeyleri Arasındaki İlişkiye Yönelik Analiz Sonuçları

\begin{tabular}{lcc}
\hline Korelasyon & $\begin{array}{l}\text { Sözel } \\
\text { Yaratıcılık }\end{array}$ & $\begin{array}{l}\text { Şekilsel } \\
\text { Yaratıcllık }\end{array}$ \\
\hline Akademik Başarı & $.29^{* *}$ & $.27^{*}$ \\
P & .009 & .01 \\
N & & 79 \\
\hline
\end{tabular}

Tablo 7 incelendiğinde öğrencilerin sözel yaratıcı düşünme düzeyleri ile akademik başarı düzeyleri arasında $29(\mathrm{p}<.01)$, şekilsel yaratıcı düşünme düzeyleri ile akademik başarı düzeyleri arasında ise $.27(\mathrm{p}<.05)$ düzeyinde pozitif bir korelasyon vardır.

\section{Tartışma, Sonuç ve Öneriler}

Akıcılık, kısa sürede çok sayıda fikir üretmektir. Esneklik, farklı boyutlarda bakabilmektir. Özgünlük ise orijinal yani diğerlerinden çok farkl fikirler üretmektir. TYDT sözel testinden elde edilen bulgular incelendiğinde, öğrencilerin sözel akıcılık puanlarının en yüksek, sözel orijinallik puanlarının ise en düşük olduğu görülmüştür. Esneklik puanları ise ikinci sırada yer almaktadır. Farklı sınıf düzeylerinde yapılmış olan araştırmalar incelendiğinde öğrencilerin yaratıcılık sözel testinde ilgili ve yorumlanabilir cevapların sayısı olan akıcılık boyutundan en yüksek puanları aldıkları, sorulara daha önce hiç verilmemiş veya çok az verilmiş cevaplar verebilme olarak tanımlanan orijinallik boyutundan ise en düşük puanları aldıkları görülmüştür. Bu sonuçlar konuyla ilgili literatürle de paralellik göstermektedir (Çetingöz, 2002; Palamut,2008; Ersoy ve Başer, 2009; Demirtaş ve Baltaoğlu, 2010). Bu sonuçlardan hareketle öğrencilerin testlerdeki sorulara ilgili ve yorumlanabilir cevaplar verebildikleri, fakat sorulara ilişkin yeni ve farklı cevaplar bulma konusunda o kadar başarılı olmadıkları söylenebilir. Bu sonuçların ortaya çıkmasının Türkiye'de uygulanan eğitim sisteminin öğrencileri özgün ürünler ortaya koyabilecekleri çalışmalar konusunda yeterince yönlendirmemesi, öğrencilerin başarılarını ise üretilen projelerle ya da ortaya konulan eserlerle değil salt test tekniğiyle ölçmesinden kaynaklandığ 1 düşünülmektedir. Şekilsel yaratıcılık açısından ise; öğrencilerin en yüksek puanı akıcılık, en düşük ortalama puanın ise başlıkların soyutluğu bölümünden aldıkları görülmüştür. Konuyla ilgili yapılan diğer çalışmalar incelendiğinde genellikle en yüksek puanların akıcılık alt boyutundan alındığı bu sonuca ulaşılmasında ise; öğrencilerin sorulara cevap verme temeline dayanan bir ölçme değerlendirme sisteminde yetişmiş olmalarının payının büyük olduğu düşünülmektedir. Ayrıca çalışma sonucunda elde edilen bulguların, konuyla ilgili yapılan araştırmaların bulgularını destekler nitelikte olduğu görülmüştür. Bu paralelde; Aral, Akyol \& Sığırtmaç (2006), anaokuluna devam eden 5-6 yaş grubundaki öğrencilerin yaratıcılıklarını inceledikleri araştırmalarında, öğrencilerin en yüksek puanı akıcılık alt başlığından aldıklarını belirlemiştir. Candar (2009), ortaokul öğrencilerinin fen eğitiminde yaratıcı düşünme becerisini incelediği çalışmasında, öğrencilerin en yüksek puanları akıcılık boyutundan aldıklarını tespit etmiştir. Meslek yüksekokulu öğrencilerinin yaratıcılıklarını TYDT şekilsel formuyla ölçen Çakmak (2010), öğrencilerin en yüksek puanları akıcılık alt boyutundan aldıklarını belirlemiştir. 
Cinsiyete göre sözel yaratıcllığın alt boyutlarında erkek öğrenciler lehine farklılıklar olsa da, istatistiksel olarak anlamlı düzeyde değildir. Yaratıcılığa yönelik cinsiyet değişkenin etkisini araştıran çalışmaların pek çoğunda, kız ve erkek çocukların yaratıcılık düzeyleri arasında anlamlı bir farklılığın bulunmadığı görülmüştür (Aydın, 1997). Ancak bu konuda farklı sonuçlarda söz konusudur. Cinsiyete göre şekilsel yaratıcılık puanlarında ise, şekilsel orijinallik ve şekilsel zenginlik açısından kız öğrenciler lehine anlamlı fark olduğu belirlenmiştir. Güngör (2007), Anadolu lisesi öğrencileriyle yapmış olduğu çalışmada öğrencilerin cinsiyete göre şekilsel yaratıcılıklarını incelemiş hemen tüm alt boyutlarda kız öğrencilerin erkek öğrencilerden daha yüksek puanlar aldıklarını görmüştür. Sonuç olarak, cinsiyete göre yaratıcılığı inceleyen pek çok çalışma yapılmıştır. Bu konudaki çalışmaların bir kısmı cinsiyet faktörünün yaratıcılık üzerinde etkisinin olmadığı yönünde iken, diğer kısmı yaratıcılığın erkeklerde kızlara oranla daha baskın olduğu yönündedir (Öztekin,2013). Bu yüzden genel olarak cinsiyetin yaratıcı düşünme açısından fark yaratan bir değişken olmadığı söylenebilir.

Öğrencilerin sözel yaratıcı düşünme düzeyleri ile şekilsel yaratıcı düşünme düzeyleri arasında anlamlı düzeyde bir ilişki vardır. Her iki testinde yaratıcılığı ölçtüğü düşünüldüğünde, bunun beklenen bir durum olduğu söylenebilir. Tok \& Sevinç (2012), düşünme becerileri eğitiminin etkisini inceledikleri araştırmalarında, düşünme eğitiminin öğrencilerin sözel ve şekilsel yaratıcılık düzeyleri üzerinde etkili olduğu sonucunu elde etmiştir. Dere (2017), yaratıcılık konusunda yaptığı çalışmada, sözel yaratıcilığ1 yüksek olan öğrencilerin, şekilsel yaratıcılık düzeylerinin de yüksek olduğunu belirlemiştir.

Akademik başarı açısından Türkçe ve Matematik derslerindeki başarı oldukça yüksektir. Bunun yanında Türkçe dersinde başarının daha yüksek olduğu gözlenmiştir. Ülkemizde genel olarak matematik dersindeki başarının düşük olduğu bilinen ve çoğu araştırma sonucuyla desteklenen bir durumdur (ABIDDE, 2018; Kocabey, 2019; ). Türk öğrencilerin matematik dersinde başarılı olamama nedenlerinin başında öğretmenlerin çoğunun benimsemiş olduğu geleneksel öğretim yöntemi gelmektedir. Bu nedenle matematik dersi öğrenciler tarafından soyut, günlük yaşantıdan uzak, değişmez kesin yargılar içeren, öğrenilmesi zor, denklemlerden oluşan bir ders olarak görülmektedir. Bunun sonucu olarak da satranç kuralları öğretimine benzer şekilde sunulan matematik dersi soğuk, sevimsiz ve ezberlenmesi gereken bir ders olmanın ötesine geçememektedir (Bütüner \& Güler, 2017). Araştırmada cinsiyete göre akademik başarı açısından anlamlı düzeyde bir farkın olmadığı belirlenmiştir. Kılıç \& Karadeniz (2004), cinsiyet ve öğrenme stilinin başarıya olan etkisini inceledikleri çalışmalarında cinsiyetin başarı üzerinde anlamlı bir etkisi olmadığı sonucuna ulaşmışlardır. Bahar (2006), eğitim fakültesindeki farklı bölümlerde eğitim gören üniversite öğrencilerinin akademik başarılarının cinsiyete göre değişip değişmediğini incelemek için yapmış olduğu çalışmada kadın öğretmen adaylarının akademik başarı puanlarının sıra ortalamalarının erkek öğretmen adaylarından fazla olduğunu, fakat bu farklılığın anlamlı derecede olmadığını belirlemiştir. Araştırmadan elde edilen diğer bir önemli sonuç da, öğrencilerin yaratıcı düşünme düzeyleri ile okuldaki akademik başarıları arasında düşük düzeyde pozitif yönde bir ilişki olduğudur. Bu sonuç Torrance(1962)'ın yaptığı çalışma ile paralellik göstermektedir. Torrance (2002), yaratıcılığın herkeste temel olarak var olduğunu, bunun miktarının kişiye ve ortamına göre değiştiğini belirtmiştir. Ayrıca okulların salt öğretimden değil yaratıcılığın geliştirilmesinden de sorumlu olduğunu belirtmiştir. Kültürel ve sosyal çevre vurgusu ile de okulların daha sosyal eğitim kurumları olma gerekliliğine vurgu yapmıştır. 
Araştırma sonuçlarından hareketle, eğitim sisteminde yaratıcılı̆̆ı geliştirici öğretim programların arttırılması önerilebilir. Araştırma öğrencilerin sözel olarak kendilerini daha iyi ifade etmelerine rağmen, farklı ve orijinal düşünme konusunda çok iyi olmadığını göstermiştir. Bu yüzden, yaratıcılığın esneklik ve özgünlük boyutlarının geliştirilmesi gereği dikkat çekmektedir. Yapılan literatür çalışması sonucunda yaratıcılığa ilişkin incelenen çalışmaların büyük çoğunluğunun sadece sözel ya da şekilsel test kullanılarak yapıldığ gözlenmiştir. Bu yüzden, her iki testin de bir arada kullanıldığı çalışmaların sayısı arttırılmalıdır. Bu çalışmada ilkokul 4. Sınıf düzeyinde, sözel ve şekilsel yaratıcılığın akademik başarı ve cinsiyet değişkeni ile olan ilişkisi incelenmiştir. Farklı sınıf düzeylerinde, sözel ve şekilsel yaratıcılığın farklı değişkenlerle olan ilişkisi de araştırılabilir.

\section{Kaynakça}

Addington, J. , E., (1997). \%100 Düşünme Gücü. (Çev: Birol Çetinkaya), Akasya Yayınları, İstanbul.

Alkan, R. (2014). Genel yaratıcılık, matematiksel yaratıcılık ve akademik başarı arasındaki ilişkilerin incelenmesi. Yüksek Lisans Tezi. Gazi Üniversitesi, Eğitim bilimleri Enstitüsü, Ankara.

Avcu, Y.E.(2014). Yaratıcı düşünme etkinliklerinin öğrencilerin yaratıcı düşünmelerine ve akademik başarılarına etkisi "coğrafya dersi örneği. Yüksek Lisans Tezi Çanakkale On Sekiz Mart Üniversitesi Eğitim Bilimleri Enstitüsü, Çanakkale.

Aydın, Z. (1997). İlköğretim 6. sını matematik dersinde kullanılan aktif öğrenme temelli etkinliklerin öğrencilerin matematik dersine karşı tutumlarına, akademik başarı ve yaratıcı düşünme düzeylerine etkisi. Yüksek Lisans Tezi. Gaziantep Üniversitesi, Sosyal Bilimler Enstitüsü, Gaziantep. ss.21.

Bahar, H. H. (2006). KPSS Puanlarının akademik başarı ve cinsiyet açısından değerlendirilmesi. Ĕ̆itim ve Bilim, 31(140).

Bütüner, S. Ö., \& Güler, M. (2017). Gerçeklerle yüzleşme: türkiye'nin tımss matematik başarısı üzerine bir çalışma. Bayburt Ĕ̆itim Fakültesi Dergisi, 12(23), 161-184.

Can, A.(2014). SPSS ile bilimsel araştırma sürecinde nicel veri analizi. (2. Baskı). Ankara: Pegem Akademi.

Candar, H. (2009). Fen eğitiminde yaratıcı düşünme öğretim tekniklerinin öğrencilerin akademik başarı, tutum ve motivasyonlarına etkisi. Yüksek Lisans Tezi, Marmara Üniversitesi Eğitim Bilimleri Enstitüsü, İstanbul

Demirtaş, V. Y., \& Baltaoğlu, G. (2010). Öğrenme stillerine göre öğrencilerin yaratıcılık düzeyleri. Education Sciences E-Journal Of New World Sciences Academy, 5(4), 2206-2215.

Dere, Z. (2017). Yaratıcılık ve geliştirilmesi dersinin öğretmen adaylarının yaratıcılıklarına etkisinin incelenmesi. Social Sciences Studies Journal, 3(10), 1192-1199.

Erdoğdu, M. Y. (2006). yaratıcılık ile öğretmen davranışları ve akademik başarı arasındaki ilişkiler. Elektronik Sosyal Bilimler Dergisi, 5(17), 95-106.

Ersoy, E., \& Başer, N. (2009). İlköğretim 6. sını öğrencilerinin yaratıcı düşünme düzeyleri. Uluslararası Sosyal Araştırmalar Dergisi, 2(9), 128-137.

Güngör, İ. (2007). Anadolu lisesi öğrencilerinin yaratıcı düşünme düzeylerinin kişisel uyum, sosyal uyum, genel yetenek ve akademik başarı ile ilişkisi. Yayınlanmamış Yüksek Lisans Tezi. Ankara Üniversitesi Eğitim Bilimleri Enstitüsü.

Karakuş, M. (2001). Eğitim ve yaratıcılık. Eğitim ve Bilim, 26, S. 119, s. 3-7.

Karasar, N. (2012). Bilimsel araştırma yöntemleri (24. baskı). Ankara: Nobel Yayınevi 
Kırışoğlu, O. T. (2002). Sanatta eğitim: görmek, öğretmek, yaratmak. Pegema Yayıncılık, Ankara, s. 20-185.

Kocabey, İ. (2019). İlkokul 4.sınf öğrencilerinin yaratıcılık ve akademik başarı düzeylerinin incelenmesi, Yayımlanmamış Yüksek Lisans Tezi, Çukurova Üniversitesi Sosyal Bilimler Enstitüsü, Adana.

Koray, Ö. (2003). Fen eğitiminde yaratıcı düşünmeye dayalı öğrenmenin öğrenme ürünlerine etkisi. Doktora Tezi, Gazi Üniversitesi Fen Bilimleri Enstitüsü, Ankara, s. 12-56.

Kurtuluş, N. (2012). Yaratıcı düşünmeye dayalı öğretim uygulamalarının bilimsel yaratıcılık bilimsel süreç becerileri ve akademik başarıya etkisi. Yüksek Lisans Tezi. Karadeniz Teknik Üniversitesi, Trabzon.

Öncü, T. (2000). Anasınıfı (6 Yaş) düzeyindeki çocukların şekilsel yaratıcılıklarının cinsiyet değişkeni açısından karşılaştırılması. Ankara Üniversitesi Dil Ve Tarih-Coğrafya Fakültesi Dergisi, 40, 25-34.

Öztekin, E.(2013). Fen bilgisi öğretmen adaylarının yaratıcı düşünme düzeylerinin farklı değişkenler açısından incelenmesi. Yüksek Lisans Tezi. Mehmet Akif Üniversitesi, Fen Bilimleri Enstitüsü, Burdur.

Öztürk, S.K. (2007). Yaratıcı düşünmeye dayalı öğrenme yaklaşımının öğrencinin yaratıcı düşünme ve problem çözme becerilerine etkisi. Yüksek Lisans Tezi, Osmangazi Üniversitesi Fen Bilimleri Enstitüsü, Eskişehir, s. 15-23.

Pala, M. (1999). Çocuk yuvalarında ve aileleriyle birlikte yaşayan 7-11 yaş grubu çocuklarda yaratıcılığın incelenmesi. Yüksek Lisans Tezi, Ankara: Ankara Üniversitesi Fen Bilimleri Enstitüsü, Ankara, s. 21-45.

Palamut, İ. (2008). Hikâye okumanın ilköğretim öğrencilerinin yaratıcılık düzeylerine ve akademik başarılarına etkisi. Doktora Tezi, DEÜ Eğitim Bilimleri Enstitüsü.

Palandökenliler, İ. (2008). İlköğretim sosyal bilgiler dersi çalışma kitaplarında yer alan etkinliklerin yaratıcı düşünme becerisi açısından değerlendirilmesi. Çukurova Üniversitesi Sosyal Bilimler Enstitüsü Eğitim Bilimleri Anabilim Dalı Yüksek Lisans Tezi.

Robinson, K. (2005). How creativity, education and the arts shape a modern economy. arts and minds. Denver, CO: Education Commission Of The States.

Torrance, E. P. (1962).Guiding creative talent. Englewood cliffs, NJ: PrenticeHall.

Torrance, E. P. (1966). Torrance test of creative thinking norms technical manual research edition. Princeton, NJ: Personel Press.

Torrance, E. P. (2002), The manifesto: a guide to developing a creative career (1. Published), USA: Ablex Publishing.

Wegerif, R. (2007). Teaching thinking: metaphors and taxonomies. Dialogic Education and Technology, 7, 125-157. 